\title{
DEPARTMENT OF EARTH SCIENCES AT THE UNIVERSITY OF ROME RADIOCARBON DATES III
}

\author{
GILBERTO CALDERONI, ${ }^{1}$ ISABELLA CANEVA, ${ }^{2}$ ALBERTO CAZZELLA, ${ }^{2}$ \\ MARCELLA FRANGIPANE ${ }^{2}$ and VNCENZO PETRONE ${ }^{3}$
}

\section{INTRODUCTION}

This is a partial list of archaeological samples processed between May 1990 and December 1992 at the Department of Earth Sciences Radiocarbon Dating Laboratory of the University of Rome. Most of the samples in the list, both from Italy and other countries, were related to excavations carried out by researchers at the University of Rome, Department of Scienze dell'Antichità. Although primarily measured for archaeological studies, some of these dates also have geological and paleoenvironmental relevance.

We used the benzene liquid scintillation technique previously reported (Calderoni and Petrone 1992). Ages were calculated on the basis of the $5568-\mathrm{yr}{ }^{14} \mathrm{C}$ half-life using NBS Oxalic Acid I and/ or ANU Sucrose as modern carbon standards. Quoted errors $( \pm 1 \sigma)$ account only for the uncertainties in activity measurements of samples, standards and backgrounds. Dates for which $\delta^{13} \mathrm{C}$ values are given were corrected to the conventional $\delta^{13} \mathrm{C}$ value of $-25 \%$.

Except as otherwise stated, wood, charcoal and peat samples underwent routine $\mathrm{HCl}, \mathrm{NaOH}$ and $\mathrm{HCl}$ chemical pretreatment. Alessio et al. (1976-1977) previously described the method for recovery and purification of bone collagen. Pretreatment of shell samples involved preliminary removal of $c a$. 15$20 \%$ of the weight with dilute $\mathrm{HCl}$.

\section{ACKNOWLEDGMENTS}

Financial support was provided by the Italian National Council of Research (CNR), National Committees 05 and 15.

\section{ITALY}

\section{Stretto di Partanna Series}

Charcoal from a ditch excavated in the settlement of Stretto di Partanna, Trapani, Sicily ( $37^{\circ} 43^{\prime}$ $\left.30^{\prime \prime} \mathrm{N}, 12^{\circ} 54^{\prime} 50^{\prime \prime} \mathrm{E}\right)$. Collected 1989 and submitted 1990 by S. Tusa, Soprintendenza per i Beni Culturali, Trapani.

Rome-290. PAR-ST-A-US15, $1.8 \mathrm{~m}$ deep $5690 \pm 100$

Rome-291. PAR-ST-A-US45, $5.3 \mathrm{~m}$ deep $6630 \pm 120$

Rome-292. PAR-ST-A-US76, 10.3 m deep

$6260 \pm 110$

\footnotetext{
${ }^{1}$ Dipartimento di Scienze della Terra, Università di Roma "La Sapienza", Piazzale Aldo Moro, 5, I-00185 Rome, Italy 2Dipartimento di Scienze dell'Antichità, Università di Roma "La Sapienza", Piazzale Aldo Moro, 5, I-00185 Rome, Italy ${ }^{3}$ Centro di Studio per il Quaternario e l'Evoluzione Ambientale (CNR) c/o Dipartimento di Scienze della Terra, Università di Roma "La Sapienza", Piazzale Aldo Moro, 5, I-00185 Rome, Italy
} 
Comment: The 3-m-wide ditch of Stretto di Partanna, excavated only in the uppermost $10.5 \mathrm{~m}$, was probably filled because it no further served as protection. The samples, from clayey-silt and ash, were associated with faunal remains, pottery, flint and obsidian tools. Rome-291, older than the deeper Rome-292, was probably reworked. In agreement with the typology of the artifacts, the dates attribute the filling phase of the ditch to the Neolithic facies of Serra d'Alto. The dates can also help outline the prehistoric sequence of the neighboring Belice valley, as well as that of comparable cultures in southern Italy (Petrone, in press).

\section{Necropolis of St. Anna Square Series}

Collagen from human bones (femurs) found in the necropolis of St. Maria Aprutiensis, St. Anna Square, downtown Teramo $\left(42^{\circ} 39^{\prime} 16^{\prime \prime} \mathrm{N}, 13^{\circ} 41^{\prime} 38^{\prime \prime} \mathrm{E}\right)$. Collected and submitted 1990 by G. Angeletti, Soprintendenza Archeologica dell'Abruzzo, Teramo.

Rome-293. Group B-Graves 25, 26, 31 and 39 $960 \pm 70$

Rome-294. Group C-Graves 44, 48 and 53 $1370 \pm 70$

Comment: The necropolis area contains remnants of both a 6th-century cathedral burned in AD 1157 and a Roman domus. Bones from two stylistically homogeneous groups of graves were dated to evaluate how long the necropolis was used. Graves of Group B (Rome-293, cal AD 1000-1160) are the farthest from the cathedral and overlie the Roman domus; Group C graves (Rome-294, cal AD $600-685$ ) cluster around the cathedral. ${ }^{14} \mathrm{C}$ ages suggest that the necropolis expanded centrifugally from the cathedral and was used during the whole life span of the cathedral.

\section{St. Anna Series}

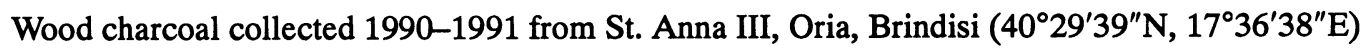
and submitted 1992 by E. Ingravallo, Dipartimento di Scienze dell'Antichità, University of Lecce. Dates are of some help in establishing the Neolithic chronology in the area, a matter still under debate.

Rome-321.

$5550 \pm 80$

Sample from fireplace, IL 8, Level 1.

$\delta^{13} C=-25.3 \%$

Rome-322.

$6780 \pm 90$

Scattered charcoal from Trench A, Level 3.

$\delta^{13} C=-25.7 \%$

Comment: There are no previous ${ }^{14} \mathrm{C}$ ages for comparable sites from the southeast Italian territory. Based on findings of painted pottery, the site was assigned to the Middle Neolithic. It shares some cultural features with the Passo di Corvo site (Tinè 1983).

Rome-216. Castel Baronia, Grave 139

$4400 \pm 80$

Charcoal from a burial in the Castel Baronia necropolis, Avellino ( $\left.41^{\circ} 02^{\prime} 29^{\prime \prime} \mathrm{N}, 15^{\circ} 10^{\prime} 53^{\prime \prime} \mathrm{E}\right)$; collected and submitted 1991 by G. Gangemi, Soprintendenza Antichità Salerno. The settlement is assigned to the Laterza facies of the Eneolithic based on archaeological association. 


\section{Conelle d'Arcevia Series}

Collagen from animal bones found during excavations at the Neolithic ditch of Conelle d'Arcevia, Ancona $\left(43^{\circ} 31^{\prime} 27^{\prime \prime} \mathrm{N}, 12^{\circ} 57^{\prime} 34^{\prime \prime} \mathrm{E}\right)$. Collected $1958-1969$ by S. M. Puglisi; submitted 1990 by A. Cazzella, Dipartimento di Scienze dell'Antichità, University of Rome.

Rome-191.

Animal bones from Trenches G (Level 8 D-E) and J (Levels 7-9).

Rome-192.

Animal bones from Trenches K (Levels 7-8) and Q (Levels 7-8).

Rome-193.

Animal bones from Trench RTE (Levels 7b-7c).

Rome-194.

Animal bones from Trenches AE, Level 12.

Rome-195.

Animal bones from Trenches AE, Level 14.

Rome-185.

Animal bones from Trench G, Level 5(C).

Rome-186.

Animal bones from Trench G, Level 6(C/D).

Rome-187.

Animal bones from Trenches RTO, Level 7.

Rome-188.

Animal bones from Trench T, Level 3.

Rome-189.

Animal bones from Trench G, Level 3(A).

Rome-190.

Animal bones from Trench G, Level 3(B).

Rome-196.

Animal bones from Trenches AD, Level 2.
$4550 \pm 70$

$\delta^{13} C=-24.0 \%$

$4500 \pm 70$

$\delta^{13} C=-23.6 \%$

$4620 \pm 75$

$\delta^{13} C=-24.0 \%$ 。

$4490 \pm 70$

$\delta^{13} C=-25.0 \%$

$4490 \pm 70$

$\delta^{13} C=-24.0 \%$

$4390 \pm 70$

$\delta^{13} C=-24.2 \%$

$4310 \pm 70$

$\delta^{13} C=-23.5 \%$ 。

$4320 \pm 70$

$\delta^{13} C=-24.6 \%$

$4500 \pm 70$

$\delta^{13} C=-24.5 \%$

$4420 \pm 70$

$\delta^{13} C=-24.1 \%$ 。

$4390 \pm 70$

$\delta^{13} C=-23.8 \%$

$4560 \pm 70$

$\delta^{13} C=-24.0 \%$ 
Comment: The ditch, ca. $120 \mathrm{~m}$ long, $7 \mathrm{~m}$ deep and 1-6 m wide, was filled by collapsed walls and accumulation of waste products, such as animal bones and potsherds, millstones and lithic industry, which assigns the site to the early Eneolithic (Cazzella 1987). ${ }^{14} \mathrm{C}$ ages from $4620-4310 \mathrm{BP}$ match those (4520-4710 BP) for the comparable ditch of Toppo Daguzzo (Cipolloni 1982).

\section{Lagoon of Venice Series}

Wood samples from St. Lorenzo di Ammiana Island, $100 \mathrm{~m}$ long and $50 \mathrm{~m}$ wide, lagoon of Venice $\left(45^{\circ} 30^{\prime} 43^{\prime \prime} \mathrm{N}, 12^{\circ} 27^{\prime} 22^{\prime \prime} \mathrm{E}\right)$. Collected 1987 and submitted 1992 by E. Canal, Ispettore della Soprintendenza Archeologica del Veneto.

\section{Rome-251. Layer V, 2 m deep}

$1600 \pm 70$

$\delta^{13} C=-26.0 \%$

Part of a pole, $10 \mathrm{~cm}$ in diameter, found in a vertical position underlying a cemetery.

Rome-253. Layer VI, $2.30 \mathrm{~m}$ deep

$1420 \pm 60$

$\mathrm{Log}, 20 \mathrm{~cm}$ in diameter, from the west corner of a wooden building.

$\delta^{13} C=-26.0 \%$

Rome-254. Layer VII, $2.60 \mathrm{~m}$ deep

Pole width holes and a longitudinal groove.

$\delta^{13} C$

Rome-255. Layer VII, $2.60 \mathrm{~m}$ deep

$1700 \pm 60$

Wooden board connected to the pole sample above, Rome- 254 .

Rome-252. Layer X, 3.00 m deep

$1870 \pm 70$

$\delta^{13} C=-27.4 \%$

Wood sample from polveroni (braided branches formerly used in the lagoon of Venice to prevent shoreline erosion by the sea).

Comment: Archaeological excavations on the island revealed remains of superimposed buildings. The calibrated ranges of ${ }^{14} \mathrm{C}$ dates for the settlements on the island are $\mathrm{AD}$ 30-230 (Rome-252) to $\mathrm{AD}$ 520-560 (Rome-253).

\section{Rome-256. Fusina \# 4}

$740 \pm 60$

$\delta^{13} C=-25.2 \%$

Part of a wooden structure at the mouth of Naviglio di Brenta River $\left(45^{\circ} 25^{\prime} 02^{\prime \prime} \mathrm{N}, 12^{\circ} 45^{\prime} 30^{\prime \prime} \mathrm{E}\right)$ for directing water to a mill. Expected age: 13th century.

Rome-329. La Cura Island

$1015 \pm 60$

$\delta^{13} C=-26.8 \%$

Wooden stake, $-3 \mathrm{~m}$ below sea level (bsl), part of an ancient shoreline protection from La Cura Island $\left(45^{\circ} 30^{\prime} 20^{\prime \prime} \mathrm{N}, 12^{\circ} 27^{\prime} 43^{\prime \prime} \mathrm{E}\right)$. 


\section{Rome-330. Serenella marsh, Murano Island}

Wooden stake, $-2 \mathrm{~m}$ bsl, part of a building foundation from Murano Island $\left(45^{\circ} 27^{\prime} 00^{\prime \prime} \mathrm{N}, 12^{\circ} 33^{\prime}\right.$ $\left.38^{\prime \prime} \mathrm{E}\right)$.

\section{Rome-331. Scanello Channel}

$1420 \pm 60$

$\delta^{13} C=-25.4 \% 0$

Wooden foundation stake, $-3 \mathrm{~m}$ bsl, from Scanello Channel $\left(45^{\circ} 29^{\prime} 25^{\prime \prime} \mathrm{N}, 12^{\circ} 27^{\prime} 56^{\prime \prime} \mathrm{E}\right)$.

\section{Rome-332. Barena dei sette Soleri}

$1720 \pm 60$

$\delta^{13} C=-24.1 \%$

Fragment of a wooden pilaster, $-2 \mathrm{~m}$ bsl, belonging to a rustic Roman villa, from Barena dei sette Soleri site $\left(45^{\circ} 32^{\prime} 55^{\prime \prime} \mathrm{N}, 12^{\circ} 27^{\prime} 48^{\prime \prime} \mathrm{E}\right)$.

\section{TURKEY}

\section{Arslantepe Series}

Since 1961, the Italian Archaeological Mission in E Anatolia, organized by the Dipartimento di Scienze dell'Antichità of the University of Rome, has carried out systematic excavations in the tell of the ancient town of Arslantepe, $912 \mathrm{~m}$ asl, Orduzu village, $5 \mathrm{~km}$ northeast Malatya, east Anatolia $\left(38^{\circ} 22^{\prime} 08^{\prime \prime} \mathrm{N}, 38^{\circ} 23^{\prime} 38^{\prime \prime} \mathrm{E}\right)$. The mound, $c a .30 \mathrm{~m}$ deep and $250 \mathrm{~m}$ long, developed from the remains of cultural stratification of Arslantepe settlements: VII-Chalcolithic; VI-Early Bronze; V-Middle and Late Bronze; IV-recent Hittite-Imperial; III-II-neo-Hittite levels; I-Roman-Byzantine epoch and Islamic (Palmieri 1978; Frangipane and Palmieri 1983). Charcoal samples collected 1987-1991 by A. Palmieri and M. Frangipane and submitted 1991 by M. Frangipane, Dipartimento di Scienze dell'Antichità, University of Rome.

\section{Arslantepe VI-Late Chalcolithic}

Rome-164. Arslantepe D6(8)

$4840 \pm 80$

Charred wood from the floor of Room A-580, Square D6(8), final level of Late Chalcolithic period.

Rome-165. Arslantepe E(61)

$4930 \pm 80$

Charred wood from Room A-582, Square E6(1), XXVth monumental building.

Rome-166. Arslantepe E6(2)-(6)

$4840 \pm 80$

Charred wood from Room A-617, Squares E6(2)-(6), XXVth monumental building.

Arslantepe VI-Early Bronze Age

Rome-173. Arslantepe E6(7-11)

$4350 \pm 75$

Charred wood from Room A-650, Squares E6(7-11), part of a huge building complex overlying Late Chalcolithic structures of Period VII. 
Rome-163. Arslantepe D8(1)

$4060 \pm 70$

Charred wood from Pit K 759 in Square D8(1).

Rome-167. Arslantepe E2 E8(9-10)

$4080 \pm 75$

Charred wood from the central pole (E2) on the floor of Room A-607, Squares E8(9-10).

Rome-168. Arslantepe FC1* E8(9-10)

$4100 \pm 75$

Charred wood from the hearth (FC1*) of Room A-607, Squares E8(9-10).

Rome-169. Arslantepe E8(9)

$3950 \pm 70$

Charred wood from the floor of Room A-607, Square E8 (9).

Rome-170. Arslantepe E8(9)

$4070 \pm 70$

Charred wood from a collapsed layer in Room A-607, Square E8(9).

Rome-170/A. Arslantepe E8(9)

$3960 \pm 70$

Additional sample from the above location.

Rome-172. Arslantepe E8(9)

$4080 \pm 75$

Charred grain from the same location as Rome-170 and -170/A.

Rome-171. Arslantepe E8(9)

$4090 \pm 75$

Charred wood from a collapsed layer in Room A-607/2d, Square E8(9).

Rome-161. Arslantepe E8(10)

$3930 \pm 70$

Charred wood from Room A-573, Square E8(10).

Rome-162. Arslantepe D8(1)-C7(16)

$3940 \pm 70$

Charred wood from Room A-532, Squares D8(1) and C7(16).

Rome-154. Arslantepe D7(13)

$3750 \pm 75$

Charred wood from Room A-491, Square D7(13).

Rome-155. Arslantepe E8(14)

$4000 \pm 80$

Charred tree trunk from Room A-548, Square E8(14).

Rome-156. Arslantepe E8(14)

$3950 \pm 80$

Fragments of charred wood; same location as above.

Rome-157. Arslantepe E8(10)-(11)

$3800 \pm 80$

Charred wood from Room A-516, Squares E8(10)-(11). 
Rome-174. Arslantepe E8(14)

$3830 \pm 75$

Charred grain from Room A-516, Square E8(14).

Rome-158. Arslantepe E8(13)-E9(1)

$3950 \pm 80$

Charred wood from Room A-565, Squares E8(13)-E9(1).

Rome-159. Arslantepe E8(14)

$3990 \pm 70$

Charred wood from Room A-542, Square E8(14).

Rome-160. Arslantepe E8(13-14)

$4120 \pm 80$

Charred wood from Room A-602, Squares E8(13-14).

Rome-153. Arslantepe D8(7)

$4000 \pm 75$

Charred wood from Room A-502, Square D8(7).

Arslantepe V-Late Bronze Age

Rome-152. Arslantepe D9(10)-D9(13-14)

$3450 \pm 75$

Charred wood from three adjacent rooms, A-140, -141 and -142 , of a terraced house, Squares D9(10)-D9(13-14). One of the rooms may have been a kitchen. The house is one of the best preserved features of this period.

\section{Comment:}

Period VII. Domestic structures and burials belonging to this period were previously excavated in the northeast sector of the mound (Palmieri 1978) and dated (Alessio et al. 1976, 1983). The new samples are from two superimposed levels from the west sector of the site (Frangipane 1991). Archaeological materials, identical to those of the northeast area, and the cultural aspects, typical of the regions of the upper Euphrates, are very closely linked to Amuq Phase F and correspond generally to Late Chalcolithic cultures of northern Syria and northern Mesopotamia. ${ }^{14} \mathrm{C}$ ages agree perfectly with previous ones (Alessio et al. 1976, 1983), and refine and extend the validity of the proposed archaeological chronology of the whole mound.

Period VI. During this period, Arslantepe changed to a proto-urban center; wheel-thrown pottery, architecture and glyptics were strongly influenced by Mesopotamian Late Uruk development. ${ }^{14} \mathrm{C}$ ages concordant with those previously measured for the southwest area of the site (Alessio et al. 1976, 1983) suggest that the Late Uruk period in the northern upper Euphrates regions lasted up to the 4th millennium BC.

Period V. This period belongs to Late Bronze I (LB I) and corresponds to the Middle Hittite kingdom. We infer from the ${ }^{14} \mathrm{C}$ ages that LB I in the Malatya-Elazig region includes the transition between Old and Middle Hittite kingdoms. 


\section{SUDAN}

\section{Kabbashi-Geili Series}

Shell, wood and charcoal samples from Khartoum province, Sudan, collected 1990 and submitted 1991 by I. Caneva, Dipartimento di Scienze dell'Antichità, University of Rome. The studied sites lie along a former course of Nile River, from El Kabbashi $\left(15^{\circ} 53^{\prime} \mathrm{N}, 32^{\circ} 33^{\prime} \mathrm{E}\right)$ to El Geili $\left(16^{\circ} 01^{\prime} \mathrm{N}, 32^{\circ}\right.$ $\left.39^{\prime} \mathrm{E}\right)$. Two main cultural complexes, each including prehistoric and historical phases, were found.

\section{Prehistoric Sites}

\section{Rome-259. KAH Y2}

$6630 \pm 90$

$$
\delta^{13} C=0.21 \%
$$

Freshwater shells (Pila) from Kabbashi Haitah (KAH), Square Y, Level 2. The site represents one of the oldest aspects of Mesolithic development.

\section{Rome-263. TEM T2}

$6780 \pm 90$

Freshwater shells (Pila) from Temeyin (TEM), Square T, Level 2. The cultural context matches that of the above Kabbashi Haitah.

\section{Rome-258. US Q1C}

$7300 \pm 90$

$\delta^{13} \mathrm{C}=-0.7 \%$

Freshwater shells (Pila) from Umm Singid (US), Square Q, Level 1C. The site, on rocky terrane eroded by the Wadi el Kenger, is far from the Nile River, and thus, it could record a peculiar adaptation (lacking fishing activity) of the Nilotic Mesolithic culture.

\section{Rome-257. QUAL CC2}

$6220 \pm 80$

$\delta^{13} C=-0.14 \% 0$

Freshwater shells (Pila) from El Qala'a (QAL), Square CC, Level 2. The site is the northernmost among those excavated and shows transitional features of the latest phases of the Mesolithic culture.

\section{Rome-262. KAB A2}

$6280 \pm 85$

Freshwater shells (Pila) from Kabbashi (KAB), Square A, Level 2. The site, not far from Kabbashi Haitah, provides evidence for the latest phases of Mesolithic development in the area.

\section{Historical Sites}

Rome-260. KAB C-S3

Charcoal from Tumulus C, Grave S-3 at KAB.

\section{Rome-261. KAB A-S1}

$1860 \pm 60$

Altered wood from Tumulus A, Grave S-1, KAB. The site was sporadically used as a burial area in historical times. 
Rome-242. GEI S-159

$$
\begin{array}{r}
1990 \pm 65 \\
\delta^{13} C=-25.2 \% 0
\end{array}
$$

Altered wood from the Early Meroitic Grave S-159 in the common cemetery of El Geili (GEI).

\section{Rome-241. GEI S-171}

Altered wood from the Early Meroitic Grave S-171, GEI cemetery.

Rome-240. GEI S-155

Altered wood from Late Meroitic Grave S-155, GEI cemetery.

\section{Rome-243. GEQ T-1}

Altered wood from Late Meroitic Tumulus 1 at El Geili Sharq (GEQ).
$1960 \pm 70$

$\delta^{13} C=-24.0 \%$

$$
\begin{array}{r}
1710 \pm 65 \\
\delta^{13} C=-24.0 \%
\end{array}
$$

$$
\begin{array}{r}
1730 \pm 65 \\
\delta^{13} C=-23.2 \% \circ
\end{array}
$$

Comment: These prehistoric sites represent hunting-fishing-gathering settlements and belong to the Early Khartoum culture of the Mesolithic context. Comparisons with similar cultures from central Sudan, previously dated at $9370 \pm 110$ (HAR-3475, Khabir 1985) and $6150 \pm 80$ (T-6645, Caneva 1988), indicate that the economy and settlement patterns did not change appreciably with time. The only distinctive character is a strong Saharan influence on the latest pottery from el Kabbashi and el Qalaa at the turn of the 6th millennium BC. The historical sites fully represent the Meroitic civilization, which, because of nomadic populations, is recorded only by cemeteries.

\section{LIBYA}

\section{Acacus Series}

Wood charcoal collected 1991 from the Uan Tabu rockshelter site, Tadrart Acacus, Libyan Sahara $\left(24^{\circ} 46^{\prime} 20^{\prime \prime} \mathrm{N}, 10^{\circ} 32^{\prime} 12^{\prime \prime} \mathrm{E}\right)$ and submitted 1992 by E. Garcea, Dipartimento di Scienze dell'Antichità, University of Rome. The samples provide further ages for the Early Neolithic in the area.

Rome-292.

$8800 \pm 100$

Sample from Square 1A, Level 13.

Rome-293.

$8880 \pm 100$

Sample from Square 1D, Level 14. $\delta^{13} C=-24.4 \%$

Rome-294.

$8470 \pm 90$

Sample from Square 2A, Level 17.

Rome-295.

$8870 \pm 100$

Sample from Square 2A, Level 9.

Rome-296.

$8850 \pm 100$

Sample from Square 1D, Level 5. 
Rome-297.

$8600 \pm 90$

Sample from Square 1D, Level 2.

$\delta^{13} C=-24.5 \%$

Comment: The Uan Tabu shelter has been known since the early 1960 s for its pastoral rock paintings and a $255-\mathrm{cm}$-thick anthropogenic deposit accumulated from the late Pleistocene through early Holocene. The uppermost $2 \mathrm{~m}$ of the deposit contain abundant remnants of lithic industry comparable to the Early Neolithic of neighboring nearby sites. Previous dates (BO-191, $-192,-193$ and -195$)^{4}$ bracket the age of deposits between $8635 \pm 70$ and $8840 \pm 90 \mathrm{BP}$ (A. Salomoni, personal communication, 1992). Although osteological analyses are still underway, preliminary data suggest that Uan Tabu represents one of the earliest examples of animal domestication throughout the Sahara.

\section{REFERENCES}

Alessio, M., Allegri, L., Bella, F., Calderoni, G., Cortesi, C., Improta, S. and Petrone, V. $1983{ }^{14} \mathrm{C}$ dating of Arslantepe. In Frangipane, M. and Palmieri, A, eds., Perspectives on Protourbanization in Eastern Anatolia: Arslantepe (Malatya). Origini 12(2): 575-580.

Alessio, M., Bella, F., Calderoni, G., Cortesi, C. and Improta, S. 1976-1977 Carbon-14 dating of bone collagen from the upper Paleolithic Palidoro deposit. Quaternaria 19: 181-186.

Alessio, M., Bella, F., Improta, S., Belluomini, G., Calderoni, G., Cortesi, C. and Turi, B. 1976 University of Rome carbon-14 dates XIV. Radiocarbon 18(3): 321349.

Calderoni, G. and Petrone, V. 1992 Department of Earth Sciences at the University of Rome radiocarbon dates I. Radiocarbon 34(1): 105-113.

Caneva, I. 1988 El Geili-The history of a middle Nile environment $7000 \mathrm{BC}-\mathrm{AD}$ 1500. In Cambridge Monographs in African Archaeology 29. BAR International Series 424, Oxford, British Archaeological Reports.

Cazzella, V. 1987 Una struttura difensiva eneolitica: Il fossato di Conelle di Arcevia. In Le Marche: Archeologia, Storia, Territorio. Ancona, Istituto regionale per la

Pre-Protostoria nelle Marche-Arcevia-Sassoferrato.

Cipolloni, M. 1982 Ambiente, economia e società dall' eneolitico all'età del bronzo in Italia sud-orientale. Dialoghi di Archeologia 4(2): 27-38.

Frangipane, M. 1991 The 1990 excavations at Arslantepe, Malatya. Kazi Sonuçlari Toplantisi 13:177-195.

Frangipane, M. and Palmieri, A. 1983 Perspectives on protourbanization in Eastern Anatolia: Arslantepe (Malatya). Origini 12(2): 87-575, 580-668.

Khabir, A.R.1985 A note on the excavation of a Neolithic site in the Sarurab area, Khartoum province. Nyame Akuma 26: 40.

Palmieri, A. 1978 Scavi ad Arslantepe (Malatya). CNR: Quaderni de la Ricerca Scientifica 100: 3-44.

Petrone, V. 1994 Datazioni radiometriche con il metodo del carbonio-14 di un insediamento in contrada Stretto di Partanna (Trapani). Atti del Convegno La Preistoria del Basso Belice e della Sicilia Meridionale nel Quadro della Preistoria Siciliana e Meridionale. Palermo, Società Siciliana per la Storia Patria.

Tine, S. 1983 Passo di Corvo e la Civilta Neolitica del Tavoliere. Genova, SAGEP: 201 p.

${ }^{4} \mathrm{BO}$ designates the ${ }^{14} \mathrm{C}$ laboratory at ENEA in Bologna, directed by Dr. A. Salomoni. 